\title{
FREQUENCY OF POST-OPERATIVE COMPLICATIONS OF THYROIDECTOMY.
}

1. MBBS, M.S (General Surgery) Senior Registrar

Department of Surgery

Liaquat University of Medical \& Health Sciences Jamshoro.

2. MBBS, M.S (General Surgery) Assistant Professor

Department of Surgical Unit-II Liaquat University of Medical \& Health Sciences Jamshoro.

3. MBBS, FRCS (Ireland), Dip Laparoscopy (France)

Associate Professor

Department of Surgical Unit-III

Dow University of Health Sciences,

Karachi.

Correspondence Address:

Dr. Muhammad Rafique Pathan

Department of Surgery

Liaquat University of Medical \&

Health Sciences Jamshoro.

m_rafique_pathan@yahoo.com

Article received on:

02/02/2019

Accepted for publication:

$18 / 05 / 2019$

Received after proof reading:

30/09/2019

\begin{abstract}
Muhammad Rafique Pathan', Muhammad Qasim Mallah², Mujeeb Rehman Abbasi ${ }^{3}$
\end{abstract}
\begin{abstract}
Objectives: The objective of this study is to determine the frequency of postoperative complications of thyroidectomy. Study Design: Observational study. Setting: LUMHS Jamshoro at the Surgery Department. Period: January 2016 to December 2017. Material and Method: During these two years all the patients visiting surgery department with thyroid swelling were assessed. Assessment of thyroid swelling was done by detailed history and clinical examination. For further assessment of the swelling thyroid function tests (serum T3, T4, TSH level), ultrasound, isotope scanning and FNAC was performed. Assessed post-operative complications of thyroidectomy. Results: After assessment thyroidectomy was performed in 143 patients. Among them there were 37 males and 106 females. The ages of patients were in the range of $15-55$ years and mean age was found to be 38 years. All of these patients have visited us due to complain of thyroid swelling. After complete assessment it was found that most commonly diagnosed thyroid swelling was multinodular goitre (51.04\%). On ultrasound findings $60 \%$ of patients showed solid consistency whereas cystic and mixed were found in less patients. Post-operative complications were found in 61 patients (42.6\%). Hypocalcaemia was the most frequent complication found in $14.68 \%$ of patients. Conclusion: Thyroidectomy is a commonly performed procedure in endocrine surgery with low morbidity and mortality. Despite improvements in surgical techniques and anaesthetic equipment, the rate of complications in thyroidectomy is constant. Post-operative measurement of calcium levels in susceptible patients can prevent tetany and emergency room admissions.
\end{abstract}

Key words: $\quad$ Frequency, Postoperative Complications, Thyroidectomy.

Article Citation: Pathan MR, Mallah MQ, Abbasi MR. Frequency of post-operative complications of thyroidectomy. Professional Med J 2019; 26(10):16601664. DOI: 10.29309/TPMJ/2019.26.10.3205

\section{INTRODUCTION}

Thyroidectomy is a common and safe procedure in endocrine surgery, has low mortality and morbidity rates. With recent advancement in surgical techniques and antiseptic measures, complications with thyroidectomy have decreased. Complications in thyroidectomy is frequently associated with expertise of the surgeon. In specialized centres, thyroidectomy has zero mortality and fewer complications reported. ${ }^{1}$ Most common indications for thyroidectomy are toxic nodules, multinodular goitre, graves disease and malignancy. ${ }^{2}$ Most common complications of total thyroidectomy are recurrent laryngeal nerve palsy and transient hypocalcaemia. Post-operative hypocalcaemia is the most frequent cause of emergency hospital admissions, it can be treated immediately by intravenous calcium infusion. ${ }^{3}$ Post-operative hypoparathyroidism associated with thyroidectomy is multifactorial. It could be due to specific surgical techniques, resection of parathyroid glands, vascular injury to parathyroid gland. Thyroid pathologies like graves' disease, multinodular goitre and thyroid malignancy are associated with extensive surgical resection, hence higher risk of parathyroid gland removal. ${ }^{4}$ Thyroidectomy is one of the most frequent surgeries performed in iodine deficient areas due to increased incidence of goitre. ${ }^{5}$ Recurrent goitre is also common in iodine deficient areas. Multiple surgeries performed for recurrent goitre can cause extensive scarring and tissue handling leads to damage to parathyroid gland and surrounding structures. Hence with multiple surgeries relative risk of recurrent laryngeal nerve injury and vascular injury. ${ }^{6}$ Reviewing the possible complications of thyroidectomy, minimally invasive thyroid surgery for removal of thyroid 
nodules have been started. Although there are no large-scale conducted on the effectiveness of minimally invasive surgery. In 2002, outcomes for minimally invasive thyroid surgery were studied from 4 specialized centres and it was found that it offers less post-operative stress and good cosmetic results. ${ }^{7}$ Recurrent laryngeal nerve palsy is a long known adverse effect of thyroid surgery and its incidence is around $3.48 \% .^{8}$ Although advancement in surgical techniques and anaesthetic procedures have led to decreased incidence of other complications but the rate of RLN palsy remains same. RLN palsy causes hoarseness of voice and swallowing problems. ${ }^{9}$ Other complications like bleeding, hematoma formation and wound infection can be reduced with the help of CT scan and MRI. ${ }^{10}$ Hematoma formation is a life-threatening complication of thyroid surgery, its risk has been reduced over time. It causes upper airway compromise and sudden death. Studies performed on identifying risk factors for hematoma formation concluded that outpatient thyroidectomy is the single most important risk factor. Hence outpatient thyroidectomy is not widely accepted procedure by experienced surgeons. ${ }^{11}$

\section{METHOD}

This study was conducted in LUMHS Jamshoro at the surgery department during the time period of January 2016 to December 2017. It was a two year study done to study post-operative complications of thyroidectomy. During these two years all the patients visiting surgery department with thyroid swelling were assessed. Assessment of thyroid swelling was done by detailed history and clinical examination. For further assessment of the swelling thyroid function tests (serum T3, T4, TSH level), ultrasound, isotope scanning and FNAC was performed. After definitive diagnosis of the swelling, type of thyroidectomy to be performed was decided. Post operatively all patients were kept under observation for complications.

\section{RESULTS}

After assessment thyroidectomy was performed in 143 patients. Among them there were 37 males and 106 females. The ages of patients were in the range of 15-55 years and mean age was found to be 38 years. All of these patients have visited us due to complain of thyroid swelling. Table-I shows characteristics of patients and their presenting complains. After complete assessment it was found that most commonly diagnosed thyroid swelling was multinodular goitre (51.04\%). Table-Il shows the diagnosis of all patients. On ultrasound findings $60 \%$ of patients showed solid consistency whereas cystic and mixed were found in less patients. Table-III shows FNAC findings of patients.

Post-operative complications were found in 61 patients (42.6\%). Table-IV shows the type of operation performed and post-operative complications. Hypocalcaemia was the most frequent complication found in $14.68 \%$ of patients.

\section{No. Patients Percentage}

\begin{tabular}{|l|c|c|}
\hline Gender \\
\hline Male & 37 & $25.87 \%$ \\
\hline Female & 106 & $74.12 \%$ \\
\hline
\end{tabular}

\section{Age}

\begin{tabular}{|l|c|c|}
\hline 15 to 25 years & 7 & $4.89 \%$ \\
\hline 26 to 35 years & 47 & $32.86 \%$ \\
\hline 36 to 45 years & 51 & $35.66 \%$ \\
\hline 46 to 55 years & 38 & $26.57 \%$ \\
\hline
\end{tabular}

\section{Socio economic Status}

\begin{tabular}{|l|l|l|}
\hline Poor & 22 & $15.38 \%$ \\
\hline Middle class & 87 & $60.83 \%$ \\
\hline Upper class & 34 & $23.77 \%$ \\
\hline
\end{tabular}

Symptoms

\begin{tabular}{|c|c|c|}
\hline Thyriod swelling & 143 & $100 \%$ \\
\hline $\begin{array}{ll}\text { Cervical } & \text { lymph } \\
\text { adenopathy } & \end{array}$ & 10 & $6.99 \%$ \\
\hline Hoarseness of voice & 11 & $7.69 \%$ \\
\hline Pain in swelling & 9 & $6.29 \%$ \\
\hline Weight loss & 9 & $6.29 \%$ \\
\hline
\end{tabular}

Table-I. Characteristics of patients

\begin{tabular}{|l|c|c|}
\hline Clinical Diagnosis & $\begin{array}{c}\text { No of Patients } \\
\text { (n) }\end{array}$ & $\begin{array}{c}\text { Percentage } \\
\text { (\%) }\end{array}$ \\
\hline Simple nodule & 41 & $28.67 \%$ \\
\hline Toxic nodule & 4 & $2.79 \%$ \\
\hline Colloid goiter & 16 & $11.18 \%$ \\
\hline Multinodular goiter & 73 & $51.04 \%$ \\
\hline Carcinoma of thyroid & 9 & $6.29 \%$ \\
\hline
\end{tabular}

Table-II. Diagnosis of the patient 


\begin{tabular}{|c|c|c|}
\hline FNAC Finding & $\begin{array}{l}\text { No of } \\
\text { Patients (n) }\end{array}$ & $\begin{array}{l}\text { Percentage } \\
(\%)\end{array}$ \\
\hline Negative for malignancy & 115 & $80.41 \%$ \\
\hline Suspicion of malignancy & 10 & $6.99 \%$ \\
\hline Positive for malignancy & 10 & $6.99 \%$ \\
\hline Unsatisfactory & 8 & $5.59 \%$ \\
\hline \multicolumn{3}{|c|}{ Table-III. FNAC finding of patient } \\
\hline $\begin{array}{l}\text { Types of Operation } \\
\text { Performed }\end{array}$ & $\begin{array}{l}\text { No of Patients } \\
\text { (n) }\end{array}$ & $\begin{array}{l}\text { Percentage } \\
(\%)\end{array}$ \\
\hline Lobectomy & 27 & $18.88 \%$ \\
\hline Hemithyroidectomy & 30 & $20.97 \%$ \\
\hline Subtotal thyroidectomy & 78 & $54.54 \%$ \\
\hline $\begin{array}{l}\text { Near total } \\
\text { thyroidectomy }\end{array}$ & 5 & $3.49 \%$ \\
\hline Total thyroidectomy & 3 & $2.09 \%$ \\
\hline \multicolumn{3}{|c|}{ Post-operative complications } \\
\hline Hemorrhage & 8 & $5.59 \%$ \\
\hline Hematoma & 4 & $2.79 \%$ \\
\hline Hypocalcemia & 21 & $14.68 \%$ \\
\hline $\begin{array}{l}\text { Unilateral Recurrent } \\
\text { laryngeal nerve } \\
\text { paralysis }\end{array}$ & 6 & $4.19 \%$ \\
\hline $\begin{array}{l}\text { Bilateral Recurrent } \\
\text { laryngeal nerve } \\
\text { paralysis }\end{array}$ & 2 & $1.39 \%$ \\
\hline Hypoparathyroidism & 8 & $5.59 \%$ \\
\hline Wound infection & 10 & $6.99 \%$ \\
\hline Kilorrhea & 2 & $1.39 \%$ \\
\hline \multicolumn{3}{|c|}{$\begin{array}{c}\text { Table-IV. Type of surgery performed and post- } \\
\text { operative complications }\end{array}$} \\
\hline
\end{tabular}

\section{DISCUSSION}

Worldwide thyroidectomy is performed by surgeons of different expertise and backgrounds. Major indications for surgery are thyroid surgery are large multinodular goitre, cold nodules and malignancy. Other than medical indication it could be patient's desire to get the surgery. ${ }^{12}$ Total or subtotal thyroidectomy has been discussed in a lot of researches and there is still no definite decision. The amount of thyroid tissue to be left after surgery depends on the clinical judgment of the surgeon and previous course of disease..$^{13}$ Since total thyroidectomy brings the burden of daily thyroxin intake, subtotal thyroidectomy has been the standard resulting in euthyroid state of the patient and disease elimination. Subtotal thyroidectomy carries lower risk of recurrent laryngeal nerve injury and parathyroidectomy. ${ }^{14}$ Some researchers have supported total thyroidectomy as it provides definite disease control and similar morbidity rates ${ }^{15}$ Complications vary as it depends whether it is a primary surgery or recurrent surgery is being performed. Hospital related factors like duration of surgery, experience of the surgeon, patient load and frequency of thyroid surgery. To identify the effect of all these factors on the outcome, a multivariate analysis needs to be performed. ${ }^{16}$ Minimally invasive thyroidectomy has also been studied and its complication rates are similar to the conventional surgery. However, the frequency of permanent hypoparathyroidism is lower in minimally invasive thyroidectomy. A multiple centre study was carried out and it showed that the risk of recurrent laryngeal nerve palsy is higher than $3 \% .^{7}$ Preservation of parathyroid gland doesn't decrease the risk of post-operative hypocalcaemia. Transient hypoparathyroidism is a well-accepted outcome of total thyroidectomy. Degree and duration of hypocalcaemia can be determined by extent of thyroidectomy ${ }^{17}$ Permanent hypoparathyroidism is more commonly associated with surgery for malignancies. According to published reports the incidence of hypoparathyroidism ranges between $0.3 \%$ to $32 \%$ in overall cases. ${ }^{18}$ Aetiology behind post-operative hypocalcaemia include vascular damage, excision of the gland and hematoma formation. Post-operative hypocalcaemia is predominant in patients already having low calcium levels before surgery. ${ }^{19}$ Evidence for the impact of age on post-operative hypocalcaemia is still not clear, as some studies show that it is more common in younger patients while others show it is more common in old patients. ${ }^{20}$ Bleeding after thyroidectomy usually presents after 6 hours and outpatient or same-day thyroidectomy patients should be monitored at least 6 hours post-operatively. There are a lot of studies consistent with these reports in order to monitor for post-operative haemorrhage. Factors increasing the risk of haemorrhage are older age, thyroid malignancy, total thyroidectomy and male gender. ${ }^{21}$

\section{CONCLUSION}

Thyroidectomy is a commonly performed 
procedure in endocrine surgery with low morbidity and mortality. Despite improvements in surgical techniques and anaesthetic equipment, the rate of complications in thyroidectomy is constant. Post-operative measurement of calcium levels in susceptible patients can prevent tetany and emergency room admissions.

Copyright@ 18 May, 2019.

\section{REFRENCES}

1. Spiliotis J, Vaxevanidou A, Sergouniotis F, Tsiveriotis $\mathrm{K}$, Datsis A, Rogdakis A, et al. Risk factors and consequences of incidental parathyroidectomy during thyroidectomy. The American Surgeon. 2010; 76(4):436-41.

2. Perera M, Anabell L, Page D, Harding T, Gnaneswaran N, Chan S. Risk factors for post-thyroidectomy haematoma. The Journal of Laryngology \& Otology. 2016; 130(S1):S20-S5.

3. Nahas ZS, Farrag TY, Lin FR, Belin RM, Tufano RP. A safe and cost $\square$ effective short hospital stay protocol to identify patients at low risk for the development of significant hypocalcemia after total thyroidectomy. The laryngoscope. 2006; 116(6):906-10.

4. Wingert DJ, Friesen SR, lliopoulos JI, Pierce GE, Thomas $\mathrm{JH}$, Hermreck AS. Post-thyroidectomy hypocalcemia: incidence and risk factors. The American journal of surgery. 1986; 152(6):606-10.

5. Karamanakos SN, Markou KB, Panagopoulos K, Karavias D, Vagianos CE, Scopa CD, et al. Complications and risk factors related to the extent of surgery in thyroidectomy. Results from 2,043 procedures. Hormones (Athens). 2010; 9(4):318-25.

6. Levin K. oark AH, Duh CY, Derneure M, siperstein AE, Clark $\mathrm{OH}$. Reoperative thyroid surgery surgery. 1992; 111:604-9.

7. Miccoli P, Bellantone R, Mourad M, Walz M, Raffaelli $M$, Berti P. Minimally invasive video-assisted thyroidectomy: multiinstitutional experience. World journal of surgery. 2002; 26(8):972-5.

8. Cernea CR, Brandao LG, Hojaij FC, De Carlucci D, Montenegro FL, Plopper $\mathrm{C}$, et al. How to minimize complications in thyroid surgery? Auris Nasus Larynx. 2010; 37(1):1-5.

9. Christou N, Mathonnet M. Complications after total thyroidectomy. Journal of visceral surgery. 2013; 150(4):249-56.
10. Puzziello A, Rosato L, Innaro N, Orlando G, Avenia $\mathrm{N}$, Perigli $\mathrm{G}$, et al. Hypocalcemia following thyroid surgery: incidence and risk factors. A longitudinal multicenter study comprising 2,631 patients. Endocrine. 2014; 47(2):537-42.

11. Inabnet WB, Shifrin A, Ahmed L, Sinha P. Safety of same day discharge in patients undergoing sutureless thyroidectomy: A comparison of local and general anesthesia. Thyroid. 2008; 18(1):57-61.

12. Kakkos SK, Scopa CD, Chalmoukis AK, Karachalios DA, Spiliotis JD, Harkoftakis JG, et al. Relative risk of cancer in sonographically detected thyroid nodules with calcifications. Journal of Clinical Ultrasound. 2000; 28(7):347-52.

13. Melliere D, Etienne G, Becquemin J-P. Operation for hyperthyroidism: Methods and rationale. The American journal of surgery. 1988; 155(3):395-9.

14. Ku CF, Lo CY, Chan WF, Kung AW, Lam KS. Total thyroidectomy replaces subtotal thyroidectomy as the preferred surgical treatment for Graves' disease. ANZ journal of surgery. 2005; 75(7):528-31.

15. Barakate MS, Agarwal G, Reeve TS, Barraclough B, Robinson B, Delbridge LW. Total thyroidectomy is now the preferred option for the surgical management of Graves' disease. ANZ journal of surgery. 2002; 72(5):321-4.

16. Sosa JA, Bowman HM, Tielsch JM, Powe NR, Gordon $T A$, Udelsman $R$. The importance of surgeon experience for clinical and economic outcomes from thyroidectomy. Annals of surgery. 1998; 228(3):320.

17. Demeester-Mirkine N, Hooghe L, Van Geertruyden J, De Maertelaer V. Hypocalcemia after thyroidectomy. Archives of surgery. 1992; 127(7):854-8.

18. Chow T, Chu W, Lim B, Kwok S. Outcomes and complications of thyroid surgery: Retrospective study. Hong Kong medical journal= Xianggang yi xue za zhi. 2001; 7(3):261-5.

19. Walsh SR, Kumar B, Coveney EC. Serum calcium slope predicts hypocalcaemia following thyroid surgery. International Journal of Surgery. 2007; 5(1):41-4.

20. Moriyama T, Yamashita $H$, Noguchi $S$, Takamatsu $Y$, Ogawa T, Watanabe S, et al. Intraoperative parathyroid hormone assay in patients with Graves' disease for prediction of postoperative tetany. World journal of surgery. 2005; 29(10):1282-7.

21. Sosa JA, Mehta PJ, Wang TS, Boudourakis L, Roman SA. A population-based study of outcomes from thyroidectomy in aging Americans: At what cost? Journal of the American College of Surgeons. 2008; 206(6):1097-105. 


\begin{tabular}{|c|c|c|}
\hline \multicolumn{3}{|c|}{ AUTHORSHIP AND CONTRIBUTION DECLARATION } \\
\hline Sr. \# & Author-s Full Name & \multicolumn{1}{c|}{ Contribution to the paper } \\
\hline 1 & M. Rafique Pathan & $\begin{array}{l}\text { Conception and design, } \\
\text { Statistical expertise, Critical } \\
\text { revision of the article for } \\
\text { important intellectual content. } \\
\text { Data collection critical revision } \\
\text { of the article for important } \\
\text { intellectual content. } \\
\text { Critical revision of the article for } \\
\text { important intellectual content, } \\
\text { Drafting of the article. }\end{array}$ \\
\hline 3 & M. Qasim Mallah & Mujeeb Rehman Abbast \\
\hline
\end{tabular}

